\title{
Aberrant Subcellular Localization of Peroxisomal 3-Ketoacyl-CoA Thiolase in the Zellweger Syndrome and Rhizomelic Chondrodysplasia Punctata
}

\author{
ALAN BALFE, GERALD HOEFLER, WINSTON W. CHEN, AND PAUL A. WATKINS \\ The Kennedy Institute for Handicapped Children and Department of Neurology, Johns Hopkins University \\ School of Medicine, Baltimore, Maryland 21205
}

\begin{abstract}
Fibroblasts from patients with the inherited disorder Zellweger syndrome have few or no peroxisomes; multiple biochemical processes that normally occur in this organelle are defective. Rhizomelic chondrodysplasia punctata (RCDP) is another inherited disorder in which two unrelated peroxisomal metabolic processes, plasmalogen synthesis and phytanic acid oxidation, are impaired despite the normal appearance of peroxisomal structure. It was previously reported that one of the enzymes of peroxisomal fatty acid $\beta$-oxidation, 3-ketoacyl-CoA thiolase ( $\beta$-ketothiolase), was present in precursor rather than mature form in both of these diseases. Immunofluorescent staining for peroxisomal $\beta$-ketothiolase showed the immunoreactivity to be localized in subcellular particles in fibroblasts from both Zellweger syndrome and RCDP patients, even though the former lack normal peroxisomes. Immunoblot studies were performed to determine the subcellular location of the thiolase precursor in fractionated fibroblasts from Zellweger and RCDP patients. In both disorders, thiolase immunoreactivity was detected in subcellular fractions having a lower density than normal peroxisomes and mitochondria, and was resistant to digestion by proteinase $K$. The density of the thiolase precursor-containing fractions was similar to that of peroxisomal membrane "ghost" fractions recently described by Santos et al. (J Biol Chem 263:10502-10509, 1988). Our results suggest that these are not empty membrane vesicles but contain at least one peroxisomal matrix protein. Furthermore, they exist not only in cells in which normal peroxisomes fail to form (Zellweger syndrome), but also in some cells which have catalase-containing peroxisomes (RCDP). (Pediatr Res 27: 304-310, 1990)
\end{abstract}

\begin{abstract}
Abbreviations
$\beta$-ketothiolase or thiolase, 3-ketoacyl-CoA thiolase Bifunctional enzyme, enoyl-CoA hydratase/3-hydroxyacyl-CoA dehydrogenase bifunctional enzyme RCDP, rhizomelic chondrodysplasia punctata
\end{abstract}

Peroxisomes are subcellular organelles, present in nearly all animal and plant cells, which participate in several cellular metabolic processes (1). These include the $\beta 7 / 8$ oxidationof fatty

Received June 29, 1989; accepted October 13, 1989.

Correspondence and reprints Dr. Winston Chen, Kennedy Institute, $707 \mathrm{~N}$. Broadway, Baltimore, MD 21205.

Supported in part by Grant HD10981 from the U.S. Public Health Service. G.H. is supported by the Fonds zur Foerderung der Wissenschaftlichen Forschung J0145M. A.B. by International Research Fellowship TW03098 from the Fogarty International Center, National Institutes of Health. acids (2), particularly very long chain fatty acids $(3,4)$, synthesis of plasmalogens (5), oxidation of L-pipecolic acid $(6,7)$, and synthesis of bile acids (8). Normally, peroxisomes also contain catalase, the enzyme responsible for degrading $\mathrm{H}_{2} \mathrm{O}_{2}$ produced by peroxisomal oxidases (1).

There are several inherited human disorders in which either peroxisomal structure or metabolic function(s) are defective (911). Goldfischer et al. (12) found that in liver and kidney from infants born with the Zellweger cerebro-hepato-renal syndrome, catalase-containing peroxisomes were not morphologically detectable. Most peroxisomal functions, including $\beta$-oxidation of very long chain fatty acids, are defective in Zellweger tissues (911). The peroxisomal pathway for the $\beta$-oxidation of fatty acids contains three enzymes: acyl-CoA oxidase, a bifunctional enzyme with enoyl-CoA hydratase (EC 4.2.1.17), 3-hydroxyacylCoA dehydrogenase (EC 1.1.1.35) activities, and 3-ketoacyl-CoA thiolase ( $\beta$-ketothiolase) (EC 2.3.1.16) (13). Tager et al. (14), using immunoblot analysis, initially reported that all three enzymes were deficient in postmortem liver samples from Zellweger patients. It was subsequently observed that $\beta$-ketothiolase was present in tissues from some Zellweger patients, but its mol wt was about $3000 \mathrm{D}$ larger than the mature enzyme $(15,16)$. $\beta$ Ketothiolase is one of the few peroxisomal proteins that is known to undergo proteolytic processing; the mature enzyme found in peroxisomes is about $3000 \mathrm{D}$ smaller than the de novo synthesized polypeptide (17). Sequence analysis of cDNA clones coding for the rat (18) and human $\beta$-ketothiolase (19) suggests that the $44-\mathrm{kD}$ precursor is cleaved at a proteolytic site 26 amino acids from the amino terminus. Thus, the immunoreactive protein found in Zellweger tissues appears to be the precursor or unprocessed form of peroxisomal $\beta$-ketothiolase.

All peroxisomal proteins studied thus far, including the integral membrane proteins and the $\beta$-oxidation enzymes, are synthesized in the cytosol on free polyribosomes (17, 20-22). It is thought that in the absence of normal peroxisomes, many newly synthesized enzymes normally destined for this organelle are degraded in the cytoplasm $(9,10,23)$. One notable exception is catalase, which persists in the cytosol in Zellweger tissues $(24,25)$. Lazarow et al. (26) using immunoblot analysis detected the presence of a $22-\mathrm{kD}$ peroxisomal integral membrane protein in liver from a Zellweger syndrome patient. Subsequently, it was reported that in fractionated Zellweger fibroblasts, the $22 \mathrm{kD}$ and other peroxisomal integral membrane proteins were detected in subcellular fractions sedimenting at a density significantly lower than normal peroxisomes (23). These proteins were found to be associated with membrane vesicles, referred to as peroxisome "ghosts," by immunofluorescence (27). We now report that the unprocessed $\beta$-ketothiolase in Zellweger fibroblasts is also contained in an organelle-associated form rather than free in the cytosol. 
RCDP is a peroxisomal disorder in which peroxisomal structure appears intact, but the peroxisomal steps of plasmalogen synthesis and oxidation of phytanic acid are defective $(16,28)$. In addition, we found that the peroxisomal $\beta$-ketothiolase in RCDP tissues was in unprocessed rather than mature form (16); this finding was unexpected because $\beta$-oxidation of very long chain fatty acids was normal in these tissues. We now report that in RCDP fibroblasts, most of this unprocessed peroxisomal $\beta$ ketothiolase is associated with fractions having a density similar to peroxisome ghosts rather than peroxisomes. This work has been reported previously in an abstract (29).

\section{MATERIALS AND METHODS}

Materials and general methods. Nycodenz and Maxidens were purchased from Accurate Chemical \& Scientific Corp., Westbury, NY. Cell culture reagents were from GIBCO, Grand Island, NY. Proteinase K [EC 3.4.21.14] and affinity-purified goat antibody to rabbit IgG, conjugated to fluorescein isothiocyanate, were from Boehringer Mannheim, Indianapolis, IN. Mol wt markers for electrophoresis and protein A were from Sigma Chemical Co., St. Louis, MO. $\left[{ }^{125} \mathrm{I}\right]$ iodine $(30 \mathrm{mCi} / \mathrm{mL})$ was purchased from Amersham Corp., Arlington Heights, IL. All other reagents were of analytical grade and were obtained from commercial sources.

Antibodies against the purified rat liver peroxisomal acyl-CoA oxidase, bifunctional enzyme, and $\beta$-ketothiolase were the generous gift of Dr. Takashi Hashimoto, Shinshu University, Matsumoto, Japan. Protein A was labeled with ${ }^{125} \mathrm{I}$ according to the procedure of Greenwood et al. (30). Catalase (EC 1.11.1.6) was assayed by the method of Peters et al. (31). Succinate dehydrogenase (EC 1.3.99.1) activity was measured by the method of Pennington (32). NADPH:cytochrome $\mathrm{c}$ reductase (EC 1.6.2.5) was measured by the method of Beaufay et al. (33). Phosphoglucomutase (EC 5.4.2.2) was assayed as described by King (34). Protein was determined by the method of Lowry et al. (35). The subcellular distribution of catalase was measured in digitonintreated fibroblasts as previously described (26).

Subcellular fractionation of cultured fibroblasts. Skin fibroblasts from patients with rhizomelic chondrodysplasia punctata and Zellweger syndrome were originally obtained for diagnostic purposes. Cells were maintained in culture as previously described (36). Fibroblast homogenates were fractionated on Nycodenz/sucrose gradients as described (37). Briefly, cells harvested by gentle trypsinization were washed with $0.25 \mathrm{M}$ sucrose containing $1 \mathrm{mM}$ Tris $\left(\mathrm{Cl}^{-}\right)$, pH 7.5, and $0.1 \mathrm{mM}$ EDTA, and resuspended in this buffer. Protease inhibitors were added (final concentrations: $100 \mu \mathrm{M}$ benzamidine; pepstatin, $0.7 \mu \mathrm{g} / \mathrm{mL}$; leupeptin, $0.4 \mu \mathrm{g} / \mathrm{mL}$ ) and cells were homogenized in a precision ball-bearing homogenizer (38) using 10 passes. Homogenates were loaded directly onto a linear gradient of increasing Nycodenz concentration (15-40\%) and decreasing sucrose concentration $(0.25-0 \mathrm{M})$ over a cushion of Maxidens. All gradient solutions contained $1 \mathrm{mM}$ Tris $\left(\mathrm{Cl}^{-}\right), \mathrm{pH} 7.5,0.1 \mathrm{mM}$ EDTA, and protease inhibitors. After centrifugation in a vertical ultracentrifuge rotor for $35 \mathrm{~min}$ at $74300 \mathrm{~g}_{\mathrm{avg}}$, fractions of approximately $0.8 \mathrm{~mL}$ were collected from the bottom of the tube. The density of each fraction was determined by refractometry, using a Bausch \& Lomb refractometer (Bausch \& Lomb, Rochester, NY). Aliquots of each fraction were assayed for marker enzyme activity.

Immunoblot analysis. Fibroblast subcellular fractions were treated with ice-cold trichloroacetic acid to a final concentration of $10 \%$. Fractions were diluted 4-fold with additional $10 \%$ trichloroacetic acid and were kept at $4^{\circ} \mathrm{C}$ overnight. Precipitates were collected by centrifugation, washed twice with diethyl ether, and solubilized for $10 \mathrm{~min}$ at $95^{\circ} \mathrm{C}$ in $80-160 \mu \mathrm{L}$ of $67.5 \mathrm{mM}$ Tris $\left(\mathrm{Cl}^{-}\right)$, pH 6.8 , containing $1 \%$ SDS and $50 \mathrm{mM}$ dithiothreitol and $10 \%$ glycerol. SDS-PAGE, immunoblot analysis, and autoradiography were performed as described (39). The molecular sizes of bands on autoradiographs were estimated by comparison to mol wt standards and to immunoblots of normal human liver $(16,39)$.

Proteinase $K$ digestion. Fibroblast homogenates were prepared as described above, except that protease inhibitors were not added. Proteinase K $(0.1-0.5 \mathrm{mg} / \mathrm{mL})$, with or without $1 \%$ detergent (either SDS or triton X-100), was added and the samples were kept on ice for $30 \mathrm{~min}$. In a separate experiment, the homogenate was sonicated $(20 \mathrm{~s}$ at $50 \mathrm{~W}$, sonicator model W185D, Ultrasonics Inc., Long Island, NY) before incubating with proteinase $\mathrm{K}$. Fibroblast subcellular fractions were also treated with proteinase $\mathrm{K}(0.1 \mathrm{mg} / \mathrm{mL})$ on ice for $30 \mathrm{~min}$. Proteins were then precipitated with $10 \%$ trichloroacetic acid and immunoblot analysis was carried out using antiserum to peroxisomal $\beta$-ketothiolase (39).

Immunofluorescence. Fibroblasts grown to about $40 \%$ confluence were washed twice with cold PBS and fixed for $10 \mathrm{~min}$ with methanol at $-20^{\circ} \mathrm{C}$. After washing again with PBS, the cells were warmed to $37^{\circ} \mathrm{C}$ and incubated with rabbit antibody to peroxisomal $\beta$-ketothiolase (1:400, in PBS containing $0.05 \% \mathrm{BSA}$ ) for $1 \mathrm{~h}$. After washing three times with PBS, goat anti-rabbit antibody conjugated to fluorescein isothiocyanate was added (1:200 in PBS) and further incubated at $37^{\circ} \mathrm{C}$ for $30-40 \mathrm{~min}$. Cells were washed twice with PBS and mounted in 50\% glycerol in PBS. Epifluorescence microscopy was performed using a Nikon Fluophot V Series microscope equipped with a 200 watt high pressure mercury lamp $\left(\lambda_{\mathrm{ex}}=375-490 \mathrm{~nm} ; \lambda_{\mathrm{em}}>520 \mathrm{~nm}\right)$.

\section{RESULTS}

Subcellular catalase distribution. The subcellular distribution of catalase in digitonin-disrupted fibroblasts provides a rapid assessment of whether normal catalase-containing peroxisomes are present in cells (26). Catalase was found primarily in the soluble fraction of Zellweger fibroblasts, suggesting that peroxisomal structure was not intact (Table 1). In contrast, catalase was found in the particulate fraction of both normal cells and RCDP fibroblasts (Table 1).

Detection of peroxisomal 3-ketoacyl-CoA thiolase by immunofluorescence. Inasmuch as the $44-\mathrm{kD}$ peroxisomal $\beta$-ketothiolase precursor is immunologically detectable in tissues both from Zellweger patients (which lack peroxisomes) and RCDP patients (which contain peroxisomes) $(15,16)$, we wanted to determine the subcellular location of this enzyme. Rabbit antibody raised against purified rat liver $\beta$-ketothiolase has been shown to crossreact with both the mature $(41 \mathrm{kD})$ and precursor form $(44 \mathrm{kD})$ of the human enzyme $(14-16,40)$. Using indirect immunofluorescence, thiolase immunoreactivity was detected in fibroblasts from Zellweger and RCDP patients, as well as normal controls (Fig. 1). In control fibroblasts (Fig. $1 C$ ), a punctate pattern of immunofluorescence was observed, consistent with the known presence of mature $41-\mathrm{kD}$ thiolase in peroxisomes. A similar pattern was seen both in Zellweger (Fig. $1 A$ ) and RCDP fibroblasts (Fig. $1 B$ ), suggesting that the immunoreactive thiolase precursor is associated with a particulate subcellular structure.

Subcellular fractionation of fibroblasts and localization of peroxisomal $\beta$-ketothiolase. To confirm that the $\beta$-ketothiolase immunoreactivity was associated with a particulate subcellular structure in Zellweger cells, fibroblast homogenates were frac-

Table 1. Subcellular catalase distribution in cultured fibroblasts*

\begin{tabular}{lcc}
\hline & \% Particulate & \% Soluble \\
\hline Normal controls $(n=8)$ & $91 \pm 3 \dagger$ & $9 \pm 3$ \\
Zellweger syndrome $(n=41)$ & $12 \pm 7$ & $88 \pm 7$ \\
RCDP $(n=8)$ & $88 \pm 7$ & $12 \pm 7$ \\
\hline
\end{tabular}

* The catalase activity in the particulate and soluble fractions of digitonin-disrupted fibroblasts is expressed as percent of total recovered activity. Recoveries were $\geq 95 \%$.

$\dagger$ Mean \pm SD 

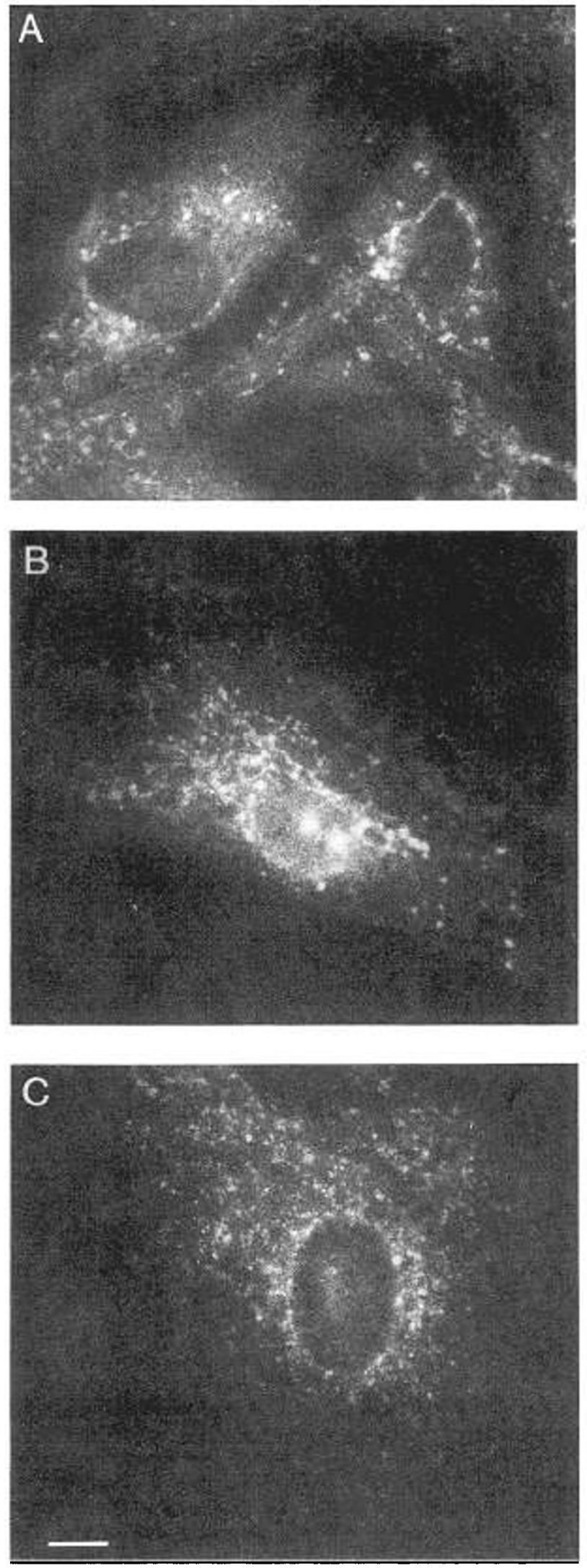

Fig. 1. Immunofluorescent detection of peroxisomal $\beta$-ketothiolase. Fibroblasts grown to about $40 \%$ confluence were fixed with cold methanol as described in Materials and Methods. Cells were incubated with rabbit antibody to peroxisomal $\beta$-ketothiolase, followed by goat antirabbit IgG conjugated to fluorescein isothiocyanate. $A$, Zellweger fibroblasts; $B, \mathrm{RCDP}$ fibroblasts; $C$, normal control fibroblasts. $B a r=10 \mu \mathrm{m}$. tionated on continuous Nycodenz-sucrose gradients. Figure 2 shows the distribution of marker enzyme activities in fibroblast subcellular fractions isolated from Nycodenz density gradients. In fibroblast fractions from either control cells or RCDP cells, catalase, a peroxisomal marker enzyme, was found at a higher density than either succinate dehydrogenase activity (a mitochondrial marker) or NADPH-cytochrome c reductase (microsomal marker). In contrast, the catalase activity in Zellweger fibroblast fractions was located at the top of gradients, along with cytosolic enzymes such as phosphoglucomutase.

Immunoblot analysis of fibroblast subcellular fractions was performed using antiperoxisomal $\beta$-ketothiolase antibody. The mature form $(41 \mathrm{kD})$ of thiolase was detected in peroxisomal (catalase-containing) fractions of normal control fibroblasts (Fig. 3). In contrast, in Zellweger fibroblasts, thiolase immunoreactivity was not detected in fractions that would normally contain peroxisomes; rather, immunoreactive protein was found in fractions having a density $(1.12-1.13 \mathrm{~g} / \mathrm{mL})$ intermediate between mitochondria and microsomes (Fig. 3). As in postmortem liver samples $(15,16)$, this enzyme had a mol wt $(44 \mathrm{kD})$ that was about $3000 \mathrm{D}$ larger than the protein found in control cells. In RCDP fibroblasts, an immunoreactive protein of the same size $(44 \mathrm{kD})$ was found mainly in lower density fractions, similar to the findings in Zellweger cells (Fig. 3); however, some immunoreactive material was detected in peroxisomal fractions (Fig. 3). A 49-kD protein, localized mainly in the mitochondrial fractions, was found to cross-react with the antiserum. This protein appears to be unrelated to the peroxisomal thiolase. It is larger than the known protein precursor of peroxisomal thiolase, the size of which has been confirmed by isolation and sequencing of the rat and human genes for peroxisomal thiolase $(18,19)$. It is also

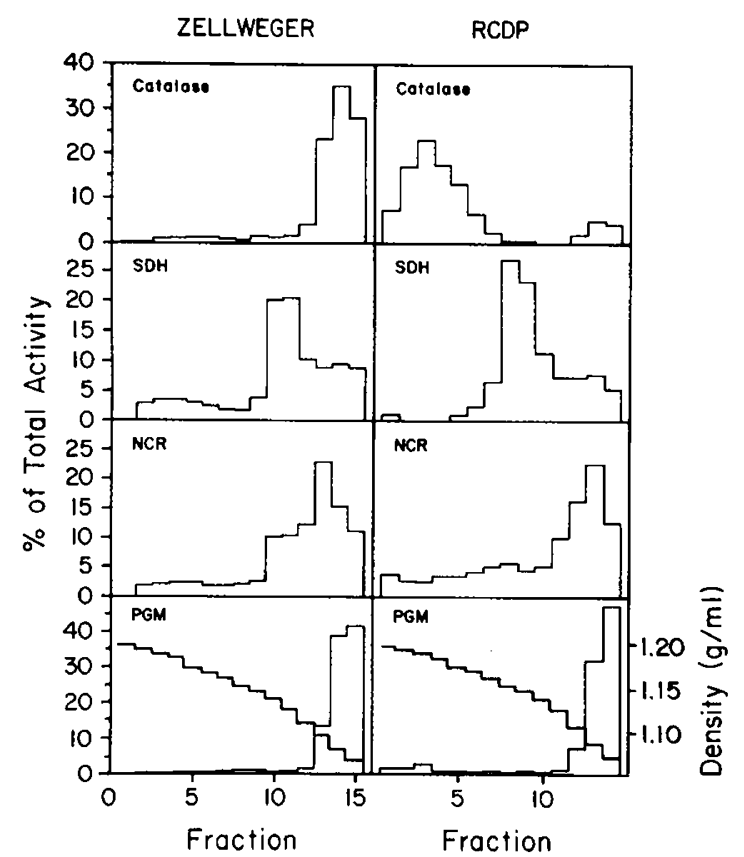

Fig. 2. Subcellular fractionation of fibroblasts from Zellweger syndrome and RCDP patients. Skin fibroblasts obtained from a Zellweger patient and a patient with RCDP were homogenized and fractionated on Nycodenz-sucrose gradients as described in Materials and Methods. The density of fractions (numbered from bottom to top of gradients) was determined and the fractions were assayed for activities of catalase (peroxisomes), succinate dehydrogenase (SDH; mitochondria), NADPH:cytochrome $\mathrm{c}$ reductase (NCR; microsomes), and phosphoglucomutase (PGM; cytosol). Results are expressed as percent of total activity across the entire gradient. Similar results were obtained with three other Zellweger and two additional RCDP cell lines. The marker enzyme distribution in RCDP cell preparations is identical to that found in control cells. 

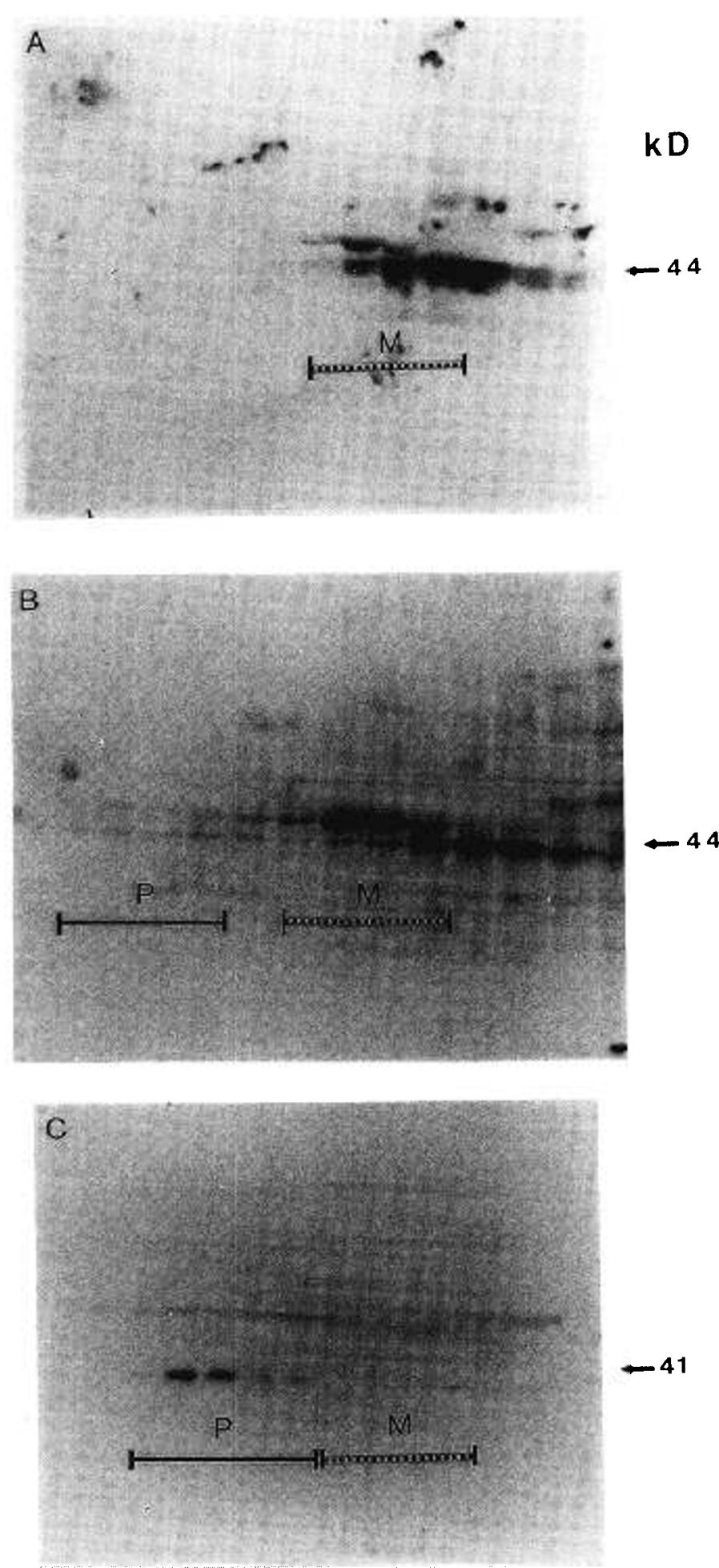

\section{Bottom}

Top

Fig. 3. Subcellular localization of peroxisomal $\beta$-ketothiolase in fractionated fibroblasts from Zellweger and RCDP patients. Trichloroacetic acid-precipitated proteins in fibroblast gradient fractions were solubilized in $1 \%$ SDS as described in Materials and Methods (fractions 1-10, 80 $\mu \mathrm{L}$; fractions $11-14,160 \mu \mathrm{L})$. Aliquots of each fraction $(40 \mu \mathrm{L})$ were subjected to SDS-PAGE and immunoblot analysis using antibody to rat liver peroxisomal 3-oxoacyl-CoA thiolase. $A$, Zellweger fibroblasts; $B$, RCDP fibroblasts; $C$, Normal control fibroblasts. Fractions enriched in peroxisomes $(P)$ and mitochondria $(M)$ are indicated by solid and dashed lines, respectively. The positions of the $44-\mathrm{kD}$ thiolase precursor ( $A$ and $B$ ) and the $41-\mathrm{kD}$ mature thiolase $(C)$ (indicated by arrows), were determined by comparison to mol wt standards and immunoblots of normal human liver. Similar results were obtained with two other RCDP cell lines and three additional Zellweger lines. larger than the monomer of mitochondrial 3-ketoacyl-CoA thiolase (41). The intensity of this cross-reacting band, relative to the peroxisomal thiolase, varied between patient and control cell lines, a reflection of the lower amounts of thiolase in the patients compared to controls.

Subcellular localization of acyl-CoA oxidase and bifunctional enzyme. Acyl-CoA oxidase and bifunctional enzyme of normal control fibroblasts were detected in the same peroxisomal subcellular fractions which contain $\beta$-ketothiolase (data not shown) (37). In RCDP fibroblasts, the 72-, 52-, and 20-kD subunits of acyl-CoA oxidase were detected mainly in peroxisomal fractions $(\rho=1.17-1.19 \mathrm{~g} / \mathrm{mL}$ ) (Fig. 4$)$, in contrast to the predominant localization of the $44-\mathrm{kD} \beta$-ketothiolase immunoreactivity in lower density fractions. The bifunctional enzyme was also detected in the peroxisomal fractions, but the intensity of the signal was low (data not shown). These antisera have been clearly shown to recognize the peroxisomal enzymes in liver preparations. In the fibroblast fractions shown here, where peroxisomal enzymes are much less abundant than in the liver, the level of other crossreacting proteins is relatively greater. Both acyl-CoA oxidase and bifunctional enzyme were below the limit of detection of the immunoblot analysis in fractions from Zellweger patients (data not shown), in agreement with previous findings in postmortem liver $(14,15)$.

Proteinase $K$ treatment of fibroblast homogenates and subcellular fractions. To determine whether the $\beta$-ketothiolase precursor in Zellweger and RCDP fibroblasts was contained inside a membranous structure or nonspecifically adsorbed to its surface, cell homogenates were incubated with proteinase $\mathrm{K}$. After incubation with the protease alone, the $44 \mathrm{kD} \beta$-ketothiolase immunoreactivity remained. The activity of the cytosolic marker enzyme phosphoglucomutase was abolished in cell homogenates in these incutations. These results suggested that the $\beta$-ketothiolase precursor of Zellweger and RCDP fibroblasts was protected from proteolysis. Sonication of the homogenates followed by digestion with proteinase $\mathrm{K}$ resulted in a significant reduction in intensity of the thiolase immunoreactive band. When digestion was carried out in the presence of detergent (either $1 \%$ SDS or $1 \%$ triton X100 ), no immunoreactive bands in the 41 to $44-\mathrm{kD}$ region remained. To verify that the immunoreactive band remaining

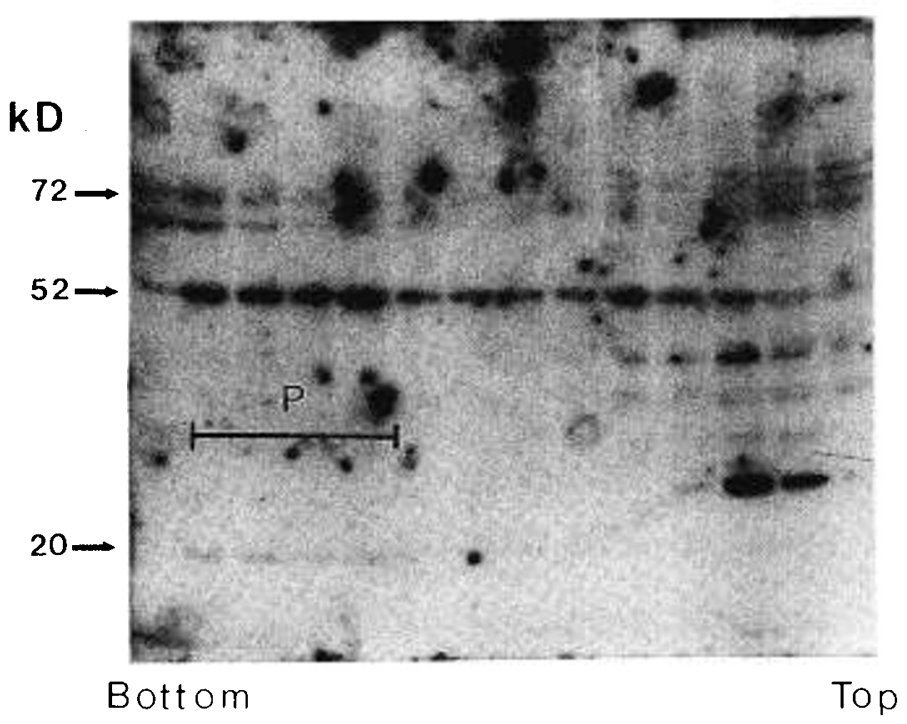

Fig. 4. Subcellular localization of peroxisomal acyl-CoA oxidase in RCDP fibroblast fractions. Gradient fractions from a patient with RCDP were subjected to SDS-PAGE electrophoresis as in Figure 3. Immunoblot analysis was performed using antibody to rat liver peroxisomal acyl-CoA oxidase. The positions of the 72-, 52-, and $20-\mathrm{kD}$ acyl-CoA oxidase subunits, determined by comparison to mol wt standards and immunoblots of normal human liver, are indicated. Similar results were obtained in studies using two other RCDP lines. 
after proteinase $\mathrm{K}$ treatment of fibroblast homogenates was indeed the $\beta$-ketothiolase precursor, Zellweger fibroblasts were fractionated and fractions incubated with protease before immunoblot analysis. Subcellular fractions containing thiolase precursor in the absence of proteinase $\mathrm{K}$ (Fig. $3 A$ ) retained an immunoreactive band of the correct mobility after protease treatment (Fig. 5). These results indicate that the $44-\mathrm{kD} \beta$ ketothiolase of Zellweger fibroblasts is located within a membranous structure that protects it from proteolysis. As a control for these experiments, the effect of protease treatment on peroxisomal acyl-CoA oxidase in RCDP fibroblast homogenates and subcellular fractions was also studied. In the absence of added detergent, the enzyme was protected from proteolysis as expected, and when detergent was added, no immunoreactive band remained after digestion (data not shown).

\section{DISCUSSION}

Subcellular fractionation of fibroblasts from patients with Zellweger syndrome revealed that the unprocessed form of $\beta$-ketothiolase is located in fractions having a density $(\rho=1.12-1.13$ $\mathrm{g} / \mathrm{mL})$ lower than normal peroxisomes $(\rho=1.17-1.19 \mathrm{~g} / \mathrm{mL})$ and mitochondria $(\rho=1.13-1.16 \mathrm{~g} / \mathrm{mL})$, but slightly higher than microsomes $(\rho \leq 1.12 \mathrm{~g} / \mathrm{mL}) .44-\mathrm{kD} \beta$-ketothiolase is not found in the cytosol where catalase is found in these peroxisomedeficient cells. Recently, Santos et al. (27) used immunofluorescence to show that although catalase-containing peroxisomes were deficient in Zellweger fibroblasts, these cells contained vesicles that reacted with antibodies to peroxisomal integral membrane proteins. Furthermore, these investigators subsequently reported that these peroxisome ghosts had a density on Nycodenz gradients that was lower than that of peroxisomes or mitochondria, and similar to that of microsomes (23). Our results suggest that the unprocessed $\beta$-ketothiolase may reside in the same peroxisome ghosts as the peroxisomal integral membrane proteins.

Whereas Zellweger fibroblasts have few recognizable peroxi-

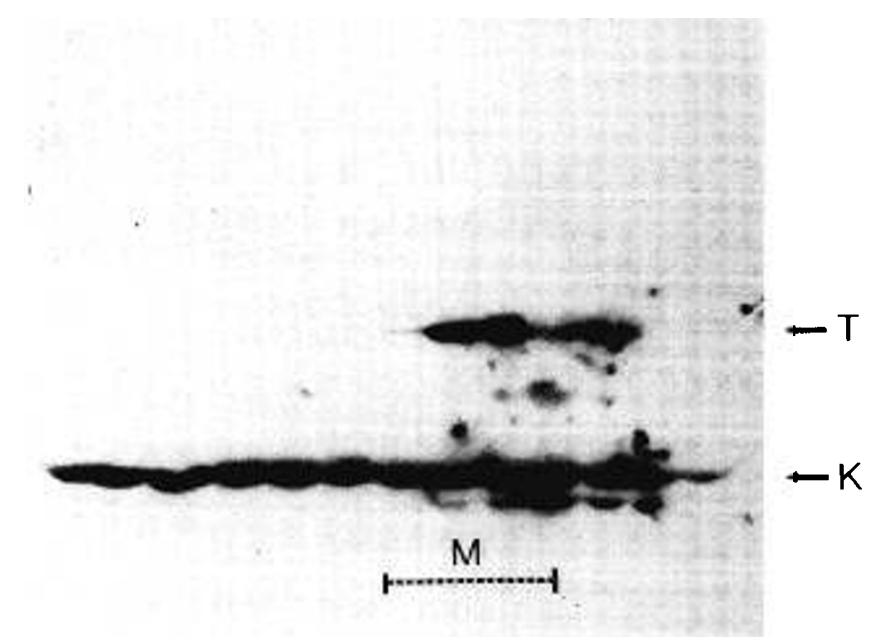

\section{Bottom}

Top

Fig. 5. Proteinase $\mathrm{K}$ treatment of fibroblast subcellular fractions. Zellweger fibroblasts were fractionated as described in Materials and Methods. Fractions were incubated for $30 \mathrm{~min}$ on ice with proteinase $\mathrm{K}$ $(0.1 \mathrm{mg} / \mathrm{mL})$ before immunoblot analysis using antiperoxisomal $\beta$-ketothiolase. Thiolase immunoreactivity is indicated by the upper arrow $(T)$. The lower band $(K)$ is observed only when proteinase $\mathrm{K}$ is present. This band is seen in immunoblots of proteinase $\mathrm{K}$ alone, and has a molecular size (about $19 \mathrm{kD}$ ) similar to that of proteinase $\mathrm{K}$. This experiment was performed on two Zellweger cell lines with similar results. Fibroblasts from the same patient were used for the experiments shown here and in Figure $3 \mathrm{~A}$. somes (42), catalase subcellular distribution studies and density gradient centrifugation experiments indicate that cells from RCDP patients clearly have catalase-containing peroxisomes.

The small amount of catalase activity in the pelleted material of Zellweger fibroblasts is in the range previously reported (24, 26), and may be due to free enzyme in the fluid trapped in the pellet, or may reflect the small number of peroxisomes which have been previously demonstrated in cultured fibroblasts from patients with Zellweger syndrome (42). Subcellular fractionation studies showed that none of the catalase in these cells was associated with a subcellular particle (Fig. 2). The small amount of soluble enzyme in control and RCDP fibroblasts is in the range previously reported for controls $(26,43)$, and may be due to breakage of some peroxisomes under the experimental conditions, or may represent newly synthesized enzyme in the cytosol, which has not yet transported to the peroxisomes. The authentic existence of extraperoxisomal catalase has been demonstrated in the liver of several mammalian species by cytochemistry and by immunoelectron microscopy (44-46).

Although infants with RCDP are profoundly retarded and have severely impaired plasmalogen synthesis and phytanic acid oxidation $(16,28)$, fibroblasts from patients affected with this fatal disorder oxidize very long chain fatty acids at normal rates (16). It was therefore surprising when we found that the peroxisomal $\beta$-ketothiolase was present in unprocessed form in postmortem liver (16) and fetal tissues (40) from RCDP patients. Our studies clearly show that most of this unprocessed $\beta$-ketothiolase is found in fractions having a lower density than peroxisomes. There was, however, weak but detectable $\beta$-ketothiolase immunoreactivity in peroxisomal subcellular fractions where catalase, acỳl-CoA oxidase, and bifunctional enzyme were localized. We must assume that this small amount of thiolase precursor in peroxisomies is sufficient to permit $\beta$-oxidation to proceed normally, although it has not been shown that the $44-\mathrm{kD}$ protein is enzymatically active.

Neither acyl-CoA oxidase nor bifunctional enzyme are detectable in liver samples (14) and cultured fibroblasts from patients with Zellweger syndrome. It is not known why $\beta$-ketothiolase immunoreactivity persists in these tissues. Schram et al. (47) showed that in Zellweger fibroblasts, acyl-CoA oxidase was synthesized but rapidly degraded. Studies in rat liver showed that both acyl-CoA oxidase and bifunctional enzyme were synthesized on free polysomes as mature proteins that were subsequently transported into peroxisomes without proteolytic modification (22). However, thiolase was synthesized on free polysomes as a precursor $3000 \mathrm{D}$ larger than the mature protein found in peroxisomes (17). No functional correlation between thiolase processing and transport into peroxisomes has been established $(18,48)$. Analysis of cDNA for the rat enzyme revealed that the precurior contained a peptide extension of 26 amino acids at its amino-terminus (18). A recent report by Bout et al. (19) revealed that a similar amino terminal extension of 26 amino acids was present in human peroxisomal thiolase. It is likely that the $41-\mathrm{kD}$ protein detected by the antiserum against rat thiolase in liver samples and cultured fibroblasts from normal individuals is the mature thiolase, and the $44-\mathrm{kD}$ protein detected in Zellweger liver and fibroblasts is the precursor. Perhaps it is the presence of the 26 amino acid extension in the thiolase precursor that protects it from the proteolytic breakdown in the cytosol, observed with acyl-CoA oxidase. Our finding that the thiolase precursor is localized in a subcellular particle may also explain its protection from intracellular degradation. It raises the possibility that the low density particles are defectively assembled peroxisomes, competent for the import of some peroxisomal proteins but not others. In RCDP cells, almost all of the peroxisomal thiolase immunoreactivity was found in the lower density fraction, despite the presence in these cells of apparently normal peroxisomes that contained the other enzymes of the peroxisomal $\beta$-oxidation pathway. Furthermore, bifunctional enzyme and the $72-$ and $20-\mathrm{kD}$ forms of acyl-CoA oxidase were undetectable in 
the lower density fractions. The $52-\mathrm{kD}$ form was localized predominantly in the peroxisomes, although it was also detectable in the lower density fractions. This dichotomy in the distribution of the $\beta$-oxidation enzymes suggests that the lower density particles are not simply immature peroxisomes.

Inasmuch as peroxisomal enzymes are synthesized in the cytoplasm and then transported to the organelle, information on targeting is thought to be contained in the polypeptide sequence. In rat liver, the peroxisomal targeting signal for $\beta$-ketothiolase may differ from that for acyl-CoA oxidase and bifunctional enzyme. The latter two enzymes contain a Ser-Lys-Leu tripeptide sequence at their carboxyl-terminus which has been shown by Gould et al. (49) to be an essential signal for peroxisomal transport of these proteins. Miyazawa et al. (50) showed that a peptide as small as the carboxyl-terminal 69 amino acids of acylCoA oxidase was effectively transported into peroxisomes in vitro. The Ser-Lys-Leu targeting sequence was not detected at the carboxyl-terminus of either rat (18) or human thiolase (19); however, two conservative variants of this tripeptide sequence are present at residue 166 (Ser-Arg-Leu) and 258 (Ala-Lys-Leu) of the human enzyme. Our observation of a preferential accumulation of the thiolase in the lower density particles in cells of RCDP patients, while other peroxisomal enzymes are in their normal peroxisomal location, may be a reflection of their different targeting signals. Our studies focus on answering this question.

Acknowledgments. The authors thank Dr. Hugo W. Moser for his encouragement and support, Dr. Takashi Hashimoto for his generous gift of antibodies to peroxisomal acyl-CoA oxidase, bifunctional enzyme, and $\beta$-ketothiolase, and Angela Liu for excellent technical assistance with cell culture.

\section{REFERENCES}

1. Tolbert NE 1981 Metabolic pathways in peroxisomes and glycosomes. Ann Rev Biochem 50:133-157

2. Lazarow PB 1978 Rat liver peroxisomes catalyze the beta-oxidation of fatty acids. J Biol Chem 253:1522-1528

3. Singh I, Moser AE, Goldfischer S, Moser HW 1984 Lignoceric acid is oxidized in the peroxisome: implications for the Zellweger cerebro-hepato-renal syndrome and adrenoleukodystrophy. Proc Natl Acad Sci USA 81:4203-4207

4. Singh H, Derwas N, Poulos A 1987 Very long chain fatty acid beta-oxidation by rat liver mitochondria and peroxisomes. Arch Biochem Biophys 259:382390

5. Hajra AK, Bishop JE 1982 Glycerolipid biosynthesis in peroxisomes via the acyl-dihydyroxyacetone phosphate pathway. Ann NY Acad Sci 386:170182

6. Mihalik SJ, Rhead WJ 1989 L-Pipecolic acid oxidation in the rabbit and cynomolgus monkey: evidence for differing organellar locations and cofactor requirements in each species. J Biol Chem 264:2509-2517

7. Wanders RJA, Romeyn GJ, van Roermund CWT, Schutgens RBH, van den Bosch H, Tager JM 1988 Identification of L-pipecolate oxidase in human liver and its deficiency in the Zellweger syndrome. Biochem Biophys Res Commun 154:33-38

8. Kase F, Bjorkhem I, Pedersen JI 1983 Formation of cholic acid from 3a, 7a 12a-thihydroxy-5B-cholestanoic acid by rat liver peroxisomes. $\mathrm{J}$ Lipid Res 24:1560-1567

9. Moser HW, Goldfischer SL 1985 The peroxisomal disorders. Hosp Pract Sept 15:61-70

10. Moser HW 1986 Peroxisomal disorders. J Pediatr 108:89-91

11. Schutgens RBH, Heymans HSA, Wanders RJA, van den Bosch H, Tager JM 1986 Peroxisomal disorders: a newly recognised group of genetic disorders. Eur J Pediatr 144:430-440

12. Goldfischer S, Moore CL, Johnson AB, Spiro AJ, Valsamis MP, Wisniewski HK, Ritch RH, Norton WT, Rapin I, Gartner LM 1973 Peroxisomal and mitochondrial defects in the cerebro-hepato-renal syndrome. Science 182:62-64

13. Hashimoto $T 1982$ Individual peroxisomal beta-oxidation enzymes. Ann NY Acad Sci 386:5-12

14. Tager JM, Van Der Beek WATH, Wanders RJA, Hashimoto T, Heymans JSA, van den Bosch H, Schutgens RBH, Schram AW 1985 Peroxisomal beta-oxidation enzyme proteins in the Zellweger syndrome. Biochem Biophys Res Commun 126:1269-1275

15. Suzuki Y, Orii T, Mori M, Tatibana T, Hashimoto T 1986 Deficient activities and proteins of peroxisomal beta-oxidation enzymes in infants with Zellweger syndrome. Clin Chim Acta 156:191-196

16. Hoefler G, Hoefler S, Watkins PA, Chen WW, Moser A, Baldwin V, McGillivary B, Charrow J, Friedman JM, Rutledge L, Hashimoto T, Moser
HW 1988 Biochemical abnormalities in rhizomelic chondrodysplasia punctata. J Pediatr 1 12:726-733

17. Fujiki Y, Rachubinski RA, Mortensen RM, Lazarow PB 1985 Synthesis of 3 ketoacyl-CoA thiolase of rat liver peroxisomes on free polyribosomes as a larger precursor. Induction of thiolase mRNA activity by clofibrate. Biochem J 226:697-704

18. Hijikata M, Ishii N, Kagamiyama H, Osumi T, Hashimoto T 1987 Structural analysis of cDNA for rat peroxisomal 3-ketoacyl-CoA thiolase. J Biol Chem 262:1851-8158

19. Bout A, Teunissen Y, Hashimoto T, Benne R, Tager JM 1988 Nucleotide sequence of human peroxisomal 3-oxoacyl-CoA thiolase. Nucleic Acids Res 16:10369

20. Goldman BM, Blobel G 1978 Biogenesis of peroxisomes: intracellular site of synthesis of catalase and uricase. Proc Natl Acad Sci USA 75:5066-5070

21. Fujiki Y, Rachubinski RA, Lazarow PB 1984 Synthesis of a major integral membrane polypeptide of rat liver peroxisomes on free polysomes. Proc Natl Acad Sci USA 81:7127-7131

22. Rachubinski RA, Fujiki Y, Mortensen RM, Lazarow PB 1985 Acyl-CoA oxidase and hydratase-dehydrogenase, two enzymes of the peroxisomal betaoxidation system, are synthesized on free polysomes of clofibrate-treated rat liver. J Cell Biol 99:2241-2246

23. Santos MJ, Imanaka T, Shio H, Lazarow PB 1988 Peroxisomal integral membrane proteins in control and Zellweger fibroblasts. J Biol Chem 263:10502-10509

24. Lazarow PB, Black B, Shio H, Fujiki Y, Hajra AK, Datta NS, Bangaru BS, Dancis J 1985 Zellweger syndrome: biochemical and morphological studies on two patients treated with clofibrate. Pediatr Res 19:1356-1364

25. Wanders RJA, Strijland A, van Roermund CWT, van den Bosch $H$, Schutgens RBH, Tager JM, Schram AW 1987 Catalase in cultured skin fibroblasts from patients with the cerebro-hepato-renal (Zellweger) syndrome: normal maturation in peroxisome-deficient cells. Biochim Biophys Acta 923:478-482

26. Lazarow PB, Fujiki Y, Small GM, Watkins P, Moser H 1986 Presence of the peroxisomal 22-k Da integral membrane protein in the liver of a person lacking recognizable peroxisomes (Zellweger syndrome). Proc Natl Acad Sci USA 87:9193-9197

27. Santos MJ, Imanaka T, Shio H, Small GM, Lazarow PB 1988 Peroxisomal membrane assembly in Zellweger syndrome-aberrant organelle assembly. Science 239:1536-1538

28. Heymans HSA, Oorthuys JWE, Nelck G, Wanders RJA, Schutgens RBH 1985 Rhizomelic chondrodysplasia punctata: another peroxisomal disorder. N Engl J Med 313:187-188

29. Balfe A, Hoefler G, Chen WW, Watkins PA 1988 Aberrant subcellular localization of peroxisomal beta-ketothiolase in human skin fibroblasts from patients with Zellweger syndrome and rhizomelic chondrodysplasia punctata. J Cell Biol 107:(6, Pt 3)121a

30. Greenwood FC, Hunter WM, Glover JS 1963 The preparation of ${ }^{131}$ I-labelled human growth hormone of high specific radioactivity. Biochem J 89:114123

31. Peters TJ, Muller M, de Duve C 1972 Lysosomes of the arterial wall I. Isolation and subcellular fractionation of cells from normal rabbit aorta. J Exp Med 136:1117-1139

32. Pennington RJ 1961 Biochemistry of dystrophic muscle. Mitochondrial succinate-tetrazolium reductase and adenosine triphosphatase. Biochem J 80:649-654

33. Beaufay $\mathrm{H}$, Amar-Costesec A, Feytmans E, Thines-Sempoux D, Wibo M, Robbi M, Berthet J 1974 Analytical study of microsomes and isolated subcellular membranes from rat liver. I. Biochemical methods. J Cell Biol 61:188-200

34. King J 1974 Phosphoglucomutase. In: Bergmeyer HU (ed) Methods of Enzymatic Analysis. Academic Press, New York, pp 798-801

35. Lowry OH, Rosebrough NJ, Farr AL, Randall RJ 1951 Protein measurement with the Folin phenol reagent. J Biol Chem 193:265-275

36. Moser HW, Moser AB, Kawamura N, Murphy J, Suzuki K, Schaumburg H, Kishimoto Y, Milunsky A 1980 Adrenoleukodystrophy: elevated C26 fatty acid in cultured skin fibroblasts. Ann Neurol 7:542-549

37. Watkins PA, Chen WW, Harris CJ, Hoefler G, Hoefler S, Blake DC, Balfe A, Kelley RI, Moser AB, Beard ME, Moser HW 1989 Peroxisomal bifunctional enzyme deficiency. J Clin Invest 83:771-777

38. Balch WE, Rothman JE 1985 Characterization of protein transport between successive compartment of the Golgi apparatus: asymmetric properties of donor and acceptor activities in a cell-free system. Arch Biochem Biophys 240:413-425

39. Chen WW, Watkins PA, Hashimoto T, Moser HW 1987 Peroxisomal betaoxidation enzymes in adrenoleukodystrophy. Proc Natl Acad Sci USA $84: 1425-1428$

40. Hoefler S, Hoefler G, Moser AB, Watkins PA, Chen WW, Hashimoto T, Moser HW 1988 Prenatal diagnosis of rhizomelic chondrodysplasia punctata. Prenat Diagn 8:571-576

41. Miyazawa S, Furuta S, Osumi T, Hashimoto T, Ui N 1981 Properties of peroxisomal 3-ketoacyl-CoA thiolase from rat liver. J Biochem 90:511-519

42. Arias JA, Moser AB, Goldfischer SL 1985 Ultrastructural and cytochemical demonstration of peroxisomes in cultured fibroblasts from patients with peroxisomal deficiency disorders. J Cell Biol 100:1789-1792

43. Wanders RJA, Kos M, Roest B, Meijer AJ, Schrakamp G, Heymans HSA, Tegelaers WHH, van den Bosch H, Schutgens RBH, Tager JM 1984 Activity of peroxisomal enzymes and intracellular distribution of catalase in Zellweger syndrome. Biochem Biophys Res Commun 123:1054-1061 
44. Roels F 1976 Cytochemical demonstration of extraperoxisomal catalase. I. Sheep liver. J Histochem Cytochem 24:713-724

45. Roels F, de Coster W, Goldfischer S 1976 Cytochemical demonstration of extraperoxisomal catalase. II. Liver of rhesus monkey and guinea pig. J Histochem Cytochem 25:157-160

46. Yamamoto K, Volkl A, Hashimoto T, Fahimi HD 1988 Catalase in guinea pig hepatocytes is localized in cytoplasm, nuclear matrix and peroxisomes. Eur J Cell Biol 46:129-135

47. Schram AW, Strijland A, Hashimoto T, Wanders RJA, Schutgens RBH, van den Bosch H, Tager JM 1986 Biosynthesis and maturation of peroxisomal beta-oxidation enzymes in fibroblasts in relation to the Zellweger syndrome and infantile Refsum disease. Proc Natl Acad Sci USA 83:6156-6158

48. Miura S, Mori M, Takaguchi M, Tatibana M, Furuta S, Miyazawa S, Hashimoto T 1984 Biosynthesis and intracellular transport of enzymes of peroxisomal beta-oxidation. J Biol Chem 259:6397-6402

49. Gould SJ, Keller G-A, Subramani S 1988 Identification of peroxisomal targeting signals located at the carboxy terminus of four peroxisomal proteins. $J$

50. Miyazawa S, Osumi T, Hashimoto T, Ohno K, Miura S, Fujiki Y 1989 Peroxisome targeting signal of rat liver acyl-Coenzyme A oxidase resides a the carboxy terminus. Mol Cell Biol 9:83-91 